\title{
Kinetics of Mn(II) oxidation by Leptothrix discophora SS1
}

\author{
Jinghao Zhang, Leonard W. Lion, Yarrow M. Nelson, Michael L. Shuler, and William C. Ghiorse
}

\begin{abstract}
The kinetics of Mn(II) oxidation by the bacterium Leptothrix discophora SS1 was investigated in this research. Cells were grown in a minimal mineral salts medium in which chemical speciation was well defined. $\mathrm{Mn}$ (II) oxidation was observed in a bioreactor under controlled conditions with $\mathrm{pH}, \mathrm{O}_{2}$, and temperature regulation. $\mathrm{Mn}(\mathrm{II})$ oxidation experiments were performed at cell concentrations between $24 \mathrm{mg} / \mathrm{L}$ and $35 \mathrm{mg} / \mathrm{L}$, over a $\mathrm{pH}$ range from 6 to 8.5 , between temperatures of $10^{\circ} \mathrm{C}$ and $40^{\circ} \mathrm{C}$, over a dissolved oxygen range of 0 to $8.05 \mathrm{mg} / \mathrm{L}$, and with $L$. discophora SS1 cells that were grown in the presence of $\mathrm{Cu}$ concentrations ranging from zero to $0.1 \mu \mathrm{M}$. Mn(II) oxidation rates were determined when the cultures grew to stationary phase and were found to be directly proportional to $\mathrm{O}_{2}$ and cell concentrations over the ranges investigated. The optimum $\mathrm{pH}$ for $\mathrm{Mn}$ (II) oxidation was approximately 7.5, and the optimum temperature was $30^{\circ} \mathrm{C}$. A Cu level as low as $0.02 \mu \mathrm{M}$ was found to inhibit the growth rate and yield of L. discophora SS1 observed in shake flasks, while $\mathrm{Cu}$ levels between 0.02 and $0.1 \mu \mathrm{M}$ stimulated the $\mathrm{Mn}$ (II) oxidation rate observed in bioreactors. An overall rate law for $\mathrm{Mn}$ (II) oxidation by L. discophora as a function of $\mathrm{pH}$, temperature, dissolved oxygen concentration (D.O.), and $\mathrm{Cu}$ concentration is proposed. At circumneutral $\mathrm{pH}$, the rate of biologically mediated $\mathrm{Mn}$ (II) oxidation is likely to exceed homogeneous abiotic $\mathrm{Mn}$ (II) oxidation at relatively low $(\approx \mu \mathrm{g} / \mathrm{L})$ concentrations of Mn oxidizing bacteria.
\end{abstract}

\section{INTRODUCTION}

Microbial intervention accounts for much of the $\mathrm{Mn}$ (II) oxidation in the environment and therefore the global cycling of $\mathrm{Mn}$ is strongly influenced by bacteria. Indeed, biologic catalysis has been well established as the dominant mechanism of Mn oxidation in circumneutral freshwater (Ghiorse, 1984; Nealson et al., 1988) and marine environments (Tebo and Emerson, 1986; Moffett, 1997). The existence of biologic rate controls on $\mathrm{Mn}$ (II) oxidation is strongly supported by the recent isolation of Mn-oxidizing enzymes and the identification of the putative genes responsible for $\mathrm{Mn}$ (II) oxidation (Tebo et al., 1997). Mn(II) oxidation governs not only the global cycling of $\mathrm{Mn}$, but also the cycling of other trace metals via coupled adsorption processes as described below. Biologic oxidation of $\mathrm{Mn}$ (II) may also control Mn removal in water treatment plants (Stumm and Morgan, 1996) and may be an important factor in corrosion of metals (Dickinson et al., 1997).

The cycling of metals in aquatic environments is controlled by an array of biogeochemical process, including adsorption, oxidation/reduction, ligand binding reactions, mineral precipitation/dissolution, and uptake by biologic organisms. Adsorption at the solid/solution interface is thought to control toxic metal residence time and phase distribution in most aquatic systems. Particulate organic material and $\mathrm{Fe} / \mathrm{Mn}$ oxides have been identified as prominent solid phases controlling transition metal adsorption (Vuceta and Morgan, 1978; Luoma and Bryan, 1981; Tessier et al., 1996; Nelson et al., 1999a; Nelson et al., 1999b; Dong et al., 2000). While trace metal adsorption to Fe oxyhydroxides has been studied extensively (Dzombak and Morel, 1990), adsorption to Mn oxides is less well characterized. Biologically oxidized Mn has recently been shown to bind $\mathrm{Pb}$ to a significantly greater extent than either colloidal $\mathrm{Fe}$ oxyhydroxide or abiotic Mn oxides (Nelson et al., 1999a). Indeed, the role of Mn oxides in controlling toxic trace metal distribution in the environment may have been underestimated because the abiotic Mn oxides widely employed in adsorption studies typically have lower specific surface areas than biologically oxidized Mn (Nelson et al., 1999a,b; Dong et al., 2000). Integration of the kinetics for biogenic Mn oxide formation into models for toxic metal interactions would likely increase their ability to predict trace metal fate and transport in natural systems. Thus, quantitative mechanistic models that predict either Mn cycling or toxic metal fate could benefit from the capacity to accurately describe bacterially catalyzed $\mathrm{Mn}$ (II) oxidation.

A rate law for the autocatalytic abiotic oxidation of $\mathrm{Mn}$ (II) was developed by Morgan and Stumm (1964). While thermodynamically favorable, abiotic $\mathrm{Mn}(\mathrm{II})$ oxidation is kinetically inhibited at $\mathrm{pH}$ values $<9.0$ and therefore it is likely that, at most ambient $\mathrm{pH}$ values, the rate of $\mathrm{Mn}$ (II) oxidation is subject to biologic control. Although there has been some prior research on the mechanisms of enzymatic catalysis of $\mathrm{Mn}$ (II) oxidation (Larsen et al., 1999; Tebo et al., 1997), no comprehensive rate equation has been proposed for microbially mediated $\mathrm{Mn}(\mathrm{II})$ oxidation kinetics.

Recent investigations have suggested that copper-dependent enzymes play a role in $\mathrm{Mn}$ (II) oxidation in three different Mn-oxidizing bacteria: Pseudomonas putida GB-1, Bacillus SG-1, and Leptothrix discophora (van Waasbergen et al., 1996; Corstjens et al., 1997; Brouwers et al., 1999; Brouwers et al., 2000a). Addition of $\mathrm{Cu}$ to culture media has been reported to increase the $\mathrm{Mn}(\mathrm{II})$ oxidizing activity of $P$. putida by a factor 
of 5 (Brouwers et al., 1999). Similarly, $1 \mu \mathrm{M}$ of $\mathrm{Cu}$ added to spore suspensions of Bacillus SG-1, that had been extracted with ethylenediaminetetraacetic acid (EDTA) (which would have removed $\mathrm{Cu}$ ions), optimally enhanced $(\approx 2 \times)$ their formation of particulate $\mathrm{Mn}$ relative to conditions with zero added $\mathrm{Cu}$ (van Waasbergen et al., 1996). In addition, Brouwers et al. (2000b) reported that $\mathrm{Cu}$ stimulated the $\mathrm{Mn}$ (II) oxidation activity of supernatants obtained from stationary-phase suspensions of $L$. discophora SS1 after the cells were grown in the presence of $\mathrm{Cu}$; however $\mathrm{Cu}$ did not stimulate $\mathrm{Mn}$ (II) oxidation when added directly to the spent medium supernatant after growth of the bacterium without added $\mathrm{Cu}$.

Prior studies of bacterially mediated Mn(II) oxidation kinetics have been performed under a variety of conditions. In most cases, at least one important physical/chemical parameter was not controlled, such as temperature, $\mathrm{pH}, \mathrm{O}_{2}$, the presence of multiple metal species, or the presence of ligands with undefined metal-binding properties in the medium. In this research, the kinetics of $\mathrm{Mn}$ (II) oxidation by $L$. discophora SS1 were investigated under well-defined bioreactor conditions. The influence of cell concentration, $\mathrm{pH}$, temperature, dissolved oxygen and $\mathrm{Cu}$ concentration on the rate of $\mathrm{Mn}$ (II) oxidation was determined using cells grown in a minimum mineral salts (MMS) medium, in which chemical speciation was defined. The bioreactor system permitted control of $\mathrm{pH}, \mathrm{O}_{2}$, and temperature during the $\mathrm{Mn}$ (II) oxidation experiments without the use of $\mathrm{pH}$ buffers that could potentially affect $\mathrm{Mn}$ coordination chemistry.

\section{MATERIAL AND METHODS}

L. discophora SS1 (American Type Culture Collection [ATCC] 43821) is a heterotrophic, freshwater proteobacterium isolated from a wetland area in Ithaca, New York (Ghiorse and Chapnick, 1983). Pure cultures of $L$. discophora SS1 have been shown to oxidize $\mathrm{Mn}$ (II) extracellularly (Adams and Ghiorse, 1985). Cultures were maintained at $4^{\circ} \mathrm{C}$ on plates of mineral salts-vitamins-pyruvate (MSVP) medium [per liter of deion-

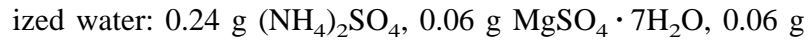
$\mathrm{CaCl}_{2} \cdot 2 \mathrm{H}_{2} \mathrm{O}, 0.02 \mathrm{~g} \mathrm{KH}_{2} \mathrm{PO}_{4}, 0.03 \mathrm{~g} \mathrm{Na}_{2} \mathrm{HPO}_{4}, 1 \mathrm{~mL}$ of 10 -mM solution $\mathrm{FeSO}_{4} \cdot 7 \mathrm{H}_{2} \mathrm{O}, 2.5 \mathrm{~mL}$ of $4 \times$ vitamin solution (Staley, 1968), $5 \mathrm{~mL}$ of Na pyruvate stock (20\%), $10 \mathrm{~mL}$ of $\mathrm{Mn}$ stock $(0.1 \mathrm{mM}), 10 \mathrm{mM}$ HEPES $(N$-2-hydrooxyethylpiperazine- $N^{\prime}$-2ethanesulfonic acid) buffer, $\mathrm{pH} 7.2$, and agar at 1.5 to $2.0 \%$ ]. Before the addition of vitamins, pyruvate, and Mn, the medium was autoclaved for $20 \mathrm{~min}$. Vitamins, pyruvate, and $\mathrm{Mn}$ (all $0.2 \mu \mathrm{m}$ filter sterilized) were then added to the solution.

Inocula from plates were first grown in $50 \mathrm{~mL}$ of a defined MMS medium (Table 1, from Nelson et al., 1999a) with 0.25 $\mathrm{mg} / \mathrm{L}$ peptone and $0.5 \mathrm{mg} / \mathrm{L}$ yeast extract added in $250-\mathrm{mL}$ flasks on a rotary shaker (New Brunswick Scientific, Innova $200)$ at $150 \mathrm{rpm}$. Inocula $(2.5 \mathrm{~mL})$ from this initial culture were then transferred to $50 \mathrm{~mL}$ MMS prepared without addition of peptone or yeast extract. When cells were in exponential growth, $2.5 \mathrm{~mL}$ were again transferred to $50 \mathrm{~mL}$ of fresh MMS medium. In some cases, this transfer sequence was repeated again to ensure that a rapidly growing population was obtained in the MMS medium. The resulting cell suspensions were used for inoculum for all subsequent experiments.

It was difficult to achieve reliable growth of $L$. discophora
Table 1. Composition of MMS medium used for growing $L$. discophora cell suspensions for measurement of $\mathrm{Mn}$ oxidation rates.

\begin{tabular}{lc}
\hline Component & $\begin{array}{c}\text { Concentration in distilled } \\
\text { deionized } \mathrm{H}_{2} \mathrm{O}(\mu \mathrm{M})\end{array}$ \\
\hline Pyruvate & 2900 \\
$\mathrm{CaCl}_{2} \cdot \mathrm{H}_{2} \mathrm{O}$ & 200 \\
$\mathrm{MgSO}_{4} \cdot 7 \mathrm{H}_{2} \mathrm{O}$ & 140 \\
$\left(\mathrm{NH}_{4}\right)_{2} \mathrm{SO}_{4}$ & 910 \\
$\mathrm{KNO}_{3}$ & 150 \\
$\mathrm{NaHCO}_{3}$ & 10 \\
$\mathrm{KH}_{2} \mathrm{PO}_{4}$ & 5 \\
$\mathrm{Vitamin}_{12}$ & 0.0015 \\
$\mathrm{FeSO}_{4}$ & 0.1 \\
\hline
\end{tabular}

The ionic strength was adjusted to $0.05 \mathrm{M}$ with $\mathrm{NaNO}_{3}$. The medium was not buffered, and the $\mathrm{pH}$ increased from 6.0 to 7.8 during cell growth.

directly in the bioreactor. Therefore, cell suspensions were first grown in shake flasks and then transferred to bioreactors for subsequent Mn oxidation under controlled conditions. Because of the use of this procedure, all Mn oxidation was measured with the culture in stationary growth phase. To prepare the cell suspensions, approximately $30 \mathrm{~mL}$ of the rapidly growing culture was then transferred to 600 to $800 \mathrm{~mL}$ MMS medium in a 1-L Erlenmeyer flask, and placed on a rotary shaker @ 150 rpm.

After the shake flask culture reached stationary phase (as measured by optical density (O.D.) at $600 \mathrm{~nm}$ ), the entire cell suspension was transferred to a stirred bioreactor that had $\mathrm{pH}$, temperature, and dissolved oxygen control as described below. The total volume of cell suspension added to each bioreactor was $0.50 \mathrm{~L}$. Dry weights of the cell suspension were determined by analyzing the total suspended solids (American Public Health Association, 1995). Oxidation of added Mn(II) was monitored by removing $20-\mathrm{mL}$ aliquots of broth at approximately $1-\mathrm{h}$ intervals for analysis of dissolved $\mathrm{Mn}$ (II) concentration. Samples were filtered through a $0.2-\mu \mathrm{m}$ membrane to remove cells and oxidized $\mathrm{Mn}$. The $\mathrm{Mn}(\mathrm{II})$ in the filtrate was analyzed by atomic absorption spectroscopy (Perkin Elmer, AAnalyst 100) with an air-acetylene flame. Replication of $\mathrm{Mn}(\mathrm{II})$ concentrations was within 5\% relative standard deviation.

Previous experiments with $L$. discophora indicated that $\mathrm{Mn}$ (II) adsorption to cells was negligible under the experimental conditions, as confirmed by the absence of $\mathrm{Mn}$ (II) release from the solid phase by rinsing with $\mathrm{CuSO}_{4}$ solution (Nelson et al., 1999a). Also, previous experiments with azide-inhibited $L$. discophora showed no decrease in soluble $\mathrm{Mn}$ (II) concentration over the course of several days (Nelson et al., 1999a), further indicating the absence of Mn(II) adsorption to the cells. Therefore, the observed loss of soluble Mn(II) from solution can be reliably attributed to $\mathrm{Mn}(\mathrm{II})$ oxidation.

The bioreactor system constructed for the study of $\mathrm{Mn}(\mathrm{II})$ oxidation kinetics is illustrated in Figure 1. Water from a constant-temperature circulating bath (Neslab, model 1162) was pumped through the bioreactor jacket to control the temperature $\left( \pm 0.1^{\circ} \mathrm{C}\right)$.

A pH controller (Cole Parmer, Chemcadet) was used to control addition of $0.01 \mathrm{~mol} / \mathrm{L}$ solutions of $\mathrm{NaOH}$ and $\mathrm{HNO}_{3}$ to 


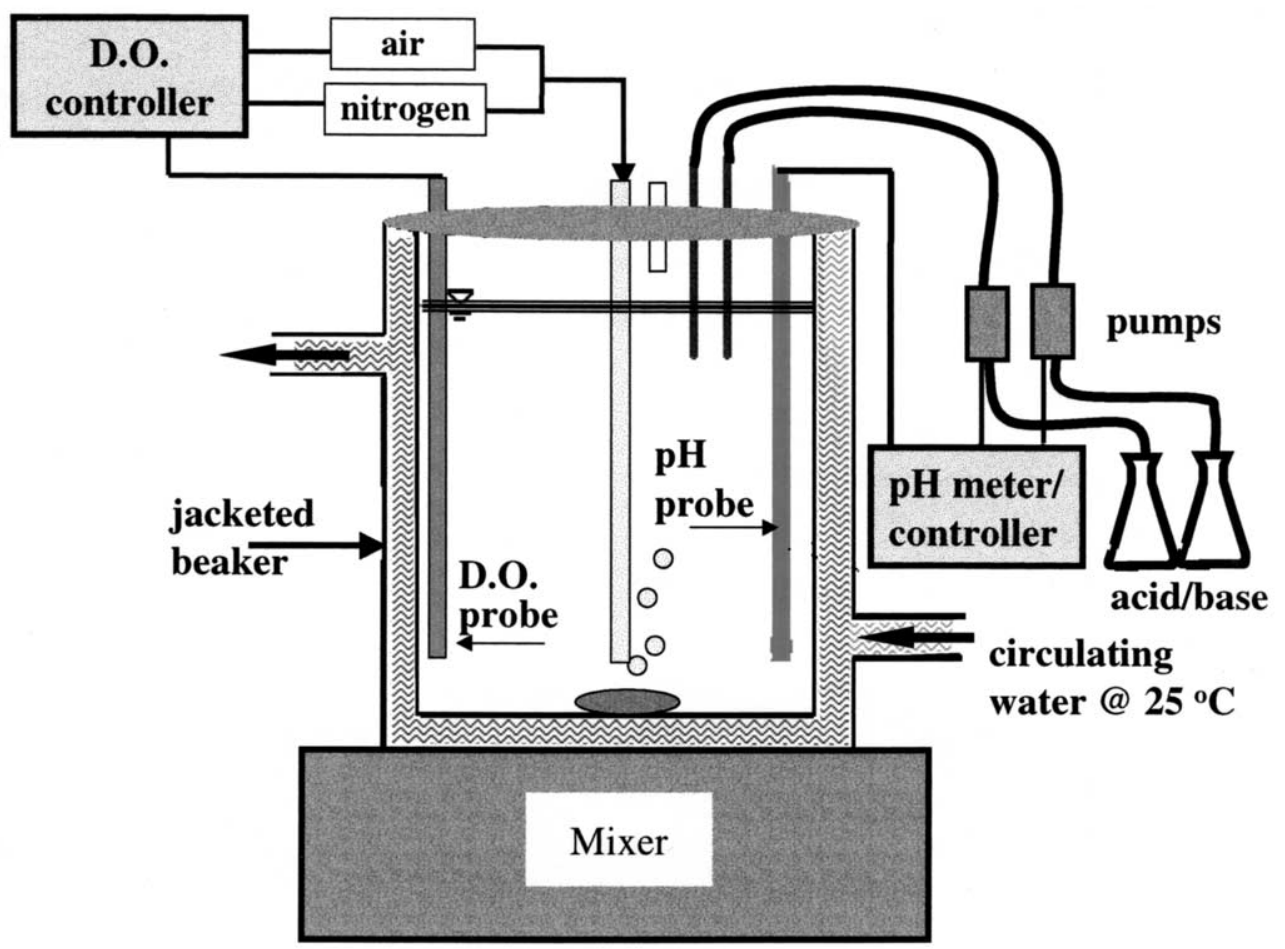

Fig. 1. Schematic drawing of the bioreactor used for study of Mn(II) oxidation kinetics under conditions of controlled temperature, $\mathrm{pH}$, and dissolved oxygen concentration.

maintain the desired $\mathrm{pH}( \pm 0.1 \mathrm{pH}$ unit). Use of $\mathrm{pH}$ control avoided the use of organic acid buffers that would be expected to bind cationic metals via their carboxyl functional groups. The metal binding constants of many commonly used organic buffers have not been determined; therefore, their use precludes knowledge of metal speciation. Alternatively, use of phosphate or carbonate buffers exacerbates the risk of forming metal precipitates at higher $\mathrm{pH}$ values. Therefore, use of simple inorganic acid and base additions in conjunction with a $\mathrm{pH}$ controller was deemed to be the preferred option for maintaining a known metal speciation.

A dissolved oxygen controller (Cole Parmer, Chemcadet) was used to regulate the flow of nitrogen and air. In experiments with variable dissolved oxygen, the bioreactor solution was purged with pure $\mathrm{N}_{2}$ and then with air to define conditions of zero dissolved $\mathrm{O}_{2}$ and $100 \%$ saturation.

The influence of copper on $\mathrm{Mn}$ (II) oxidation was tested by adding $\mathrm{Cu}$ (II) at different concentrations to MMS medium, coincident with the addition of the L. discophora SS1 inoculum. The growth of the cells with and without added $\mathrm{Cu}$ was monitored by O.D. measurement at $600 \mathrm{~nm}$. After cells grew to stationary phase, they were transferred to the jacketed bioreactor system, and the procedure described above was used to measure the $\mathrm{Mn}(\mathrm{II})$ oxidation rate.

\section{RESULTS AND DISCUSSION}

\subsection{Measurement of Mn(II) Oxidation Rates}

Typical growth curves of $L$. discophora SS1 in MMS medium in the 1-L flask cultures are shown in Figure 2. The maximum growth rate in exponential phase was $0.11 / \mathrm{h}\left(r^{2}=\right.$ $0.98)$ and the exponential death rate was $6 \times 10^{-5} / \mathrm{h}\left(r^{2}=\right.$ $0.99)$.

Preliminary experiments showed that if $\mathrm{Mn}(\mathrm{II})$ was added $24 \mathrm{~h}$ after the cells reached stationary phase, there was incomplete oxidation of added Mn(II). However, when Mn(II) was added while cells were in the early stationary phase, the Mn(II) oxidation rate was similar in bioreactors that received $\mathrm{Mn}$ (II) additions within $5 \mathrm{~h}$ of the onset of stationary phase. Thus, $\mathrm{Mn}$ (II) oxidation kinetics were reasonably constant in the first $5 \mathrm{~h}$ of the stationary phase. This result is consistent with the findings of Adams and Ghiorse (1985) who reported that the highest $\mathrm{Mn}(\mathrm{II})$ oxidizing activity of $L$. discophora SS1 was obtained in early stationary-phase cultures. In all subsequent experiments $\mathrm{Mn}$ (II) was added within the first $5 \mathrm{~h}$ of the stationary phase of growth.

\subsection{Effect of Cell Concentration}

To determine the effect of cell concentration on the rate of $\mathrm{Mn}$ (II) oxidation, a series of $\mathrm{Mn}$ (II) oxidation experiments was performed at four different cell concentrations ranging from 24 to $35 \mathrm{mg} / \mathrm{L}$ (at room temperature $\left(\approx 22^{\circ} \mathrm{C}\right), \mathrm{pH}=7.5$, and $100 \%$ air saturation). The results showed that the Mn oxidation rate was directly proportional to cell concentration, with a maximum specific oxidation rate of $0.0052 \pm 0.0005 \mu \mathrm{mol}$ $\mathrm{Mn}(\mathrm{II}) /(\mathrm{min} \cdot \mathrm{mg}$ cell $)\left(r^{2}=0.99\right)$ under these conditions.

\subsection{Effect of Mn(II) Concentration}

Biologic Mn oxidation was expected to follow MichaelisMenten enzyme kinetics, with the corresponding rate law: 


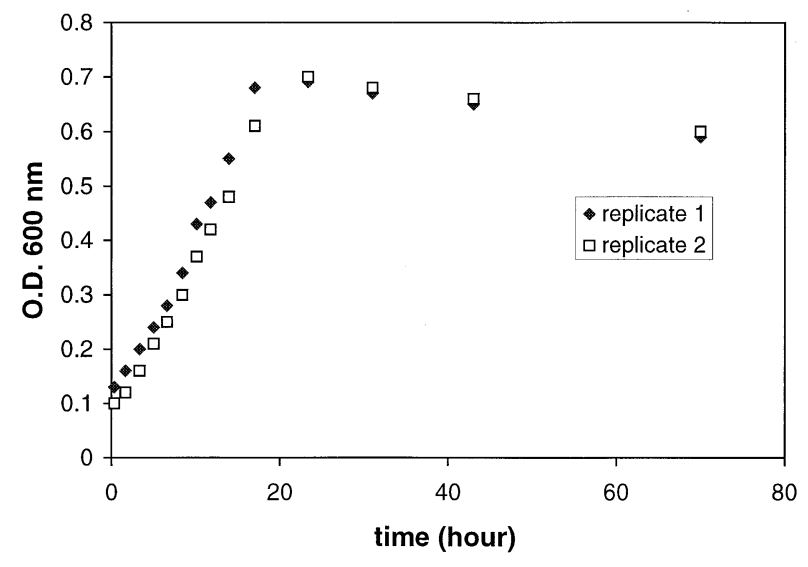

Fig. 2. Growth curve of $L$. discophora SS1. Batch cultures were grown at room temperature with no added $\mathrm{Cu}$ and without $\mathrm{pH}$ control in shake flasks with MMS medium.

$$
\frac{d M n(I I)}{[X] d t}=-\frac{k[M n(I I)]}{K_{S}+[M n(I I)]}
$$

where $K_{S}$ is the half velocity constant, (the concentration of $\mathrm{Mn}(\mathrm{II})$ when the oxidation rate is half of the maximum), $k$ is the maximum $\mathrm{Mn}(\mathrm{II})$ oxidation rate $[\mu \mathrm{mol} \mathrm{Mn}(\mathrm{II}) /(\mathrm{mg}$ cell $\min )]$, and $[X]$ is the cell concentration $(\mathrm{mg} / \mathrm{L})$.

In this model, the value of $k$ is expected to vary with $\mathrm{pH}$, temperature, dissolved oxygen concentration (D.O.), and copper concentration. When these parameters were kept constant (D.O. $=8.05 \mathrm{mg} / \mathrm{L}, \mathrm{T}=25^{\circ} \mathrm{C}, \mathrm{pH}=7.5$, and zero added $\mathrm{Cu}$ ), the $\mathrm{Mn}$ (II) oxidation rate increased with increasing $\mathrm{Mn}$ (II) concentration as described by the Michaelis-Menten model (Fig. 3). A nonlinear least squares analysis of the data gave $K_{S}=5.7 \mu \mathrm{mol} \mathrm{Mn(II)/L}$ and $k=0.0059 \mu \mathrm{mol} \mathrm{Mn(II)/}$ (min $\cdot \mathrm{mg}$ cell). This value of $k$ was used for a reference datum, $k_{\text {ref }}$, in our subsequent analysis of $\mathrm{pH}, \mathrm{O}_{2}, \mathrm{~T}$, and $\mathrm{Cu}$ effects on the $\mathrm{Mn}(\mathrm{II})$ oxidation rate. It should be noted that the $K_{S}$ we observed in these experiments is close to the value of $6 \mu \mathrm{M}$ reported by Adams and Ghiorse (1987) for Mn(II) oxidation by

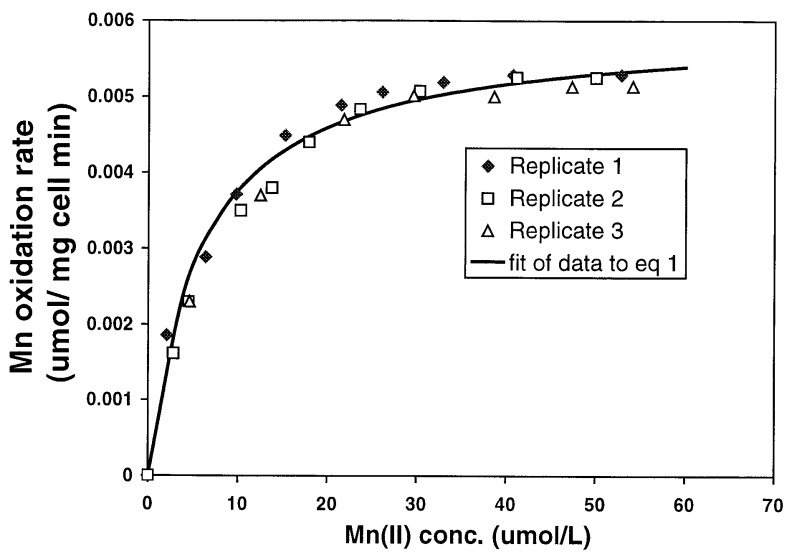

Fig. 3. $\mathrm{Mn}(\mathrm{II})$ oxidation rates as a function of $\mathrm{Mn}$ (II) concentration, showing Michaelis-Menten oxidation kinetics for $\mathrm{Mn}$ (II) at $\mathrm{T}=25^{\circ} \mathrm{C}$, $\mathrm{pH}=7.5$, and $\mathrm{O}_{2}=8.05 \mathrm{mg} / \mathrm{L}$, and zero added $\mathrm{Cu}$.

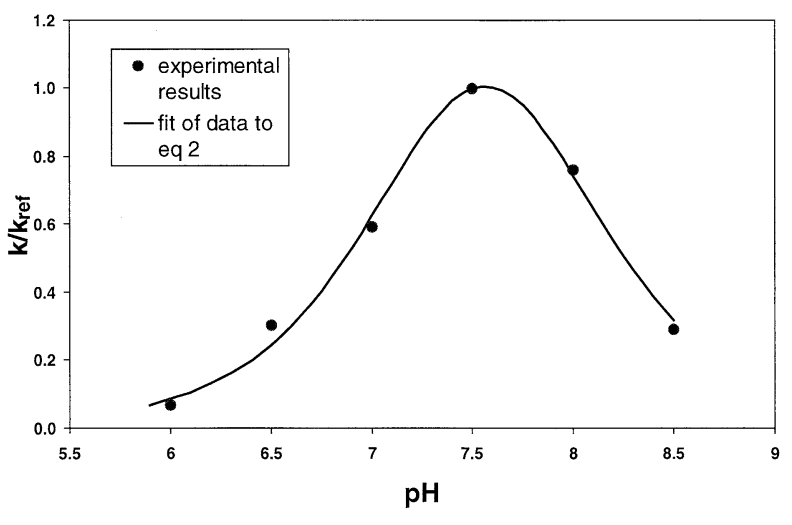

Fig. 4. $\mathrm{pH}$ influence on $\mathrm{Mn}$ (II) oxidation rate in the bioreactor at $\mathrm{T}=$ $25^{\circ} \mathrm{C}, \mathrm{O}_{2}=8.05 \mathrm{mg} / \mathrm{L}$, and zero added $\mathrm{Cu}$.

L. discophora SS1 in a complex medium in which the speciation of other metals, $\mathrm{Mn}$ (II), and metal-binding ligands was not defined. These results suggest that $K_{S}$ was not affected by the presence of undefined metals or by metal complexation with organic ligands in the previous investigations.

\subsection{Effect of $\mathbf{p H}$}

The effect of $\mathrm{pH}$ on $\mathrm{Mn}$ oxidation was explored by varying $\mathrm{pH}$ in $0.5 \mathrm{pH}$ unit intervals from 6 to 8.5 , while keeping temperature at $25^{\circ} \mathrm{C}$, D.O. $=8.05 \mathrm{mg} / \mathrm{L}$, added $\mathrm{Cu}=0$, and other conditions constant. In these experiments, a maximum in Mn oxidation rate was observed at $\mathrm{pH} 7.5$ (Fig. 4).

The observed $\mathrm{pH}$ optimum of 7.5 matches the value reported by Boogerd and de Vrind (1987) and is close to the $\mathrm{pH} 7.3$ optimum reported by Adams and Ghiorse (1987); both prior investigations used a medium in which $\mathrm{Mn}(\mathrm{II})$ speciation was not defined and that included buffers with overlapping $\mathrm{pH}$ ranges. All studies have found that the rate of biologic $\mathrm{Mn}$ (II) oxidation is strongly influenced by $\mathrm{pH}$ and is very slow at $\mathrm{pH}$ values less than 6 or greater than 8.5.

Theoretically, $\mathrm{pH}$ can affect the oxidation rate of $\mathrm{Mn}$ (II) via both the maximum reaction rate $k$, as well as the half velocity coefficient $K_{S}$. However, Bailey and Ollis (1986) suggest that $\mathrm{pH}$ effects on $K_{S}$ are usually relatively insignificant and indicate that the effect of $\mathrm{pH}$ on the maximum rate of an enzymatic reaction can be modeled by an equation of the following form:

$$
\left[\frac{k}{k_{r e f}}\right]_{p H}=\frac{k_{p H}}{1+\left[H^{+}\right] / K_{1}+K_{2} /\left[H^{+}\right]}
$$

where $k$ is the $\mathrm{Mn}(\mathrm{II})$ oxidation rate per cell, $k_{\text {ref }}=k @ \mathrm{pH}=$ 7.5, D.O. $=8.05 \mathrm{mg} / \mathrm{L}, \mathrm{T}=25^{\circ} \mathrm{C}$, added $\mathrm{Cu}=0, K_{1}$ and $K_{2}$ are constants, and $k_{p H}$ equals the value of $\left(1+\left[H^{+}\right] / K_{1}+\right.$ $\left.K_{2} /\left[H^{+}\right]\right)$determined at $\mathrm{pH}=7.5$.

Least square data analysis for the experimental data in Figure 4 gave $K_{1}=3.05 \times 10^{-8}$, and $K_{2}=2.46 \times 10^{-8}\left(r^{2}=0.99\right)$, with a resulting value of $k_{p H}=2.82$. The ability of Eqn. 2 to fit the experimental data was excellent (see Fig. 4).

Because Mn(II) speciation varies as a function of $\mathrm{pH}, \mathrm{Mn}(\mathrm{II})$ speciation could have affected the above results. Mn speciation was calculated by the chemical equilibrium program MINEQL (Westall et al., 1976) for the defined MMS medium, and is 
Table 2. Metal speciation in MMS medium as determined using the chemical speciation program MINEQL $([\mathrm{Mn}(\mathrm{II})]=50 \mu \mathrm{M},[\mathrm{Cu}(\mathrm{II})]=0.1$ $\mu \mathrm{M}, \mathrm{P}_{\mathrm{Co}_{2}}=10^{-3.5}$ atm., $\left.\mathrm{T}=25^{\circ} \mathrm{C}\right){ }^{\mathrm{a}}$

\begin{tabular}{|c|c|c|c|c|c|c|}
\hline \multirow[b]{2}{*}{ Species (\%) } & \multicolumn{6}{|c|}{$\mathrm{pH}$} \\
\hline & 6.0 & 6.5 & 7.0 & 7.5 & 8.0 & 8.5 \\
\hline $\mathrm{Mn}^{2+}$ & 78.5 & 78.5 & 78.4 & 78.2 & 35.6 & 3.6 \\
\hline $\mathrm{MnSO}_{4}$ & 10.9 & 10.9 & 10.9 & 10.0 & 5 & 0 \\
\hline $\mathrm{MnHPO}_{4}$ & 9.9 & 10 & 10 & 10 & 10 & 0 \\
\hline Rhodochrosite $\left[\mathrm{MnCO}_{3}(\mathrm{~s})\right]$ & 0 & 0 & 0 & 0 & 48.8 & 95.8 \\
\hline $\mathrm{Cu}^{2+}$ & 83.6 & 69.9 & 28.4 & 4.2 & N/A & N/A \\
\hline $\mathrm{Cu}(\mathrm{OH})^{+}$ & 0 & 2.2 & 2.8 & 1.3 & N/A & N/A \\
\hline $\mathrm{Cu}(\mathrm{OH})_{2}(\mathrm{aq})$ & 1.7 & 14.6 & 59.4 & 88.4 & N/A & N/A \\
\hline $\mathrm{CuSO}_{4}$ & 13.1 & 10.9 & 3.3 & 0 & N/A & N/A \\
\hline $\mathrm{CuCO}_{3}(\mathrm{aq})$ & 0 & 0 & 4.4 & 5 & N/A & N/A \\
\hline
\end{tabular}

N/A $=$ not applicable.

${ }^{\text {a }}$ Note that below $\mathrm{pH} 7.5$, over $78 \%$ of the total $\mathrm{Mn}$ (II) is in the aquo metal ion form, while above $\mathrm{pH} 8.0$ the speciation program predicts precipitation of $\mathrm{MnCO}_{3}(\mathrm{~s})$.

dominated by the presence of $\mathrm{Mn}^{+2}$ below $\mathrm{pH} 7.5$ (Table 2). Thus, the observed increase in $\mathrm{Mn}(\mathrm{II})$ oxidation rate between $\mathrm{pH} 6.0$ and 7.5 (Fig. 4) is most likely the result of $\mathrm{pH}$ dependent enzymatic activity rather than an influence of $\mathrm{Mn}$ (II) speciation. Above $\mathrm{pH} 7.5$, the calculated free $\mathrm{Mn}^{2+}$ ion concentration decreases with increasing $\mathrm{pH}$ because of the thermodynamically favorable precipitation of rhodochrosite $\left(\mathrm{MnCO}_{3}\right)$ (Table 2). Although a decrease in $\mathrm{Mn}^{2+}$ availability could conceivably explain the decreasing $\mathrm{Mn}$ (II) oxidation rate at high $\mathrm{pH}$, this explanation is thought to be unlikely because formation of a precipitate was not observed. Lack of a visible precipitate suggests that either a disequilibrium with atmospheric $\mathrm{CO}_{2}(\mathrm{~g})$ existed or that $\mathrm{MnCO}_{3}$ (s) was supersaturated and consequently $\mathrm{Mn}$ (II) remained as a dissolved solute over the time frame of the experiments. Additionally, if a $\mathrm{MnCO}_{3}(\mathrm{~s})$ precipitate had formed, it would have been removed by filtration along with the $\mathrm{Mn}(\mathrm{III} / \mathrm{IV})$ oxide. This removal of $\mathrm{Mn}(\mathrm{II})$ would have been attributed to $\mathrm{Mn}$ (II) oxidation and would have increased the "apparent" $\mathrm{Mn}$ (II) oxidation rate. Thus, the observed decrease in rate of $\mathrm{Mn}$ (II) oxidation above $\mathrm{pH} 7.5$ is most likely a result of $\mathrm{pH}$-dependent enzyme deactivation.

\subsection{Effect of $\mathrm{O}_{2}$ Concentration}

The effect of $\mathrm{O}_{2}$ on Mn oxidation was explored by measuring $\mathrm{Mn}$ (II) oxidation rate at different dissolved oxygen levels at $\mathrm{pH}=7.5, \mathrm{~T}=25^{\circ} \mathrm{C}$, and added $\mathrm{Cu}=0$ (Fig. 5). The observed $\mathrm{Mn}$ (II) oxidation rate was directly proportional to $\mathrm{O}_{2}$ concentration above $0.4 \mathrm{mg} / \mathrm{L}$, suggesting that all $\mathrm{O}_{2}$ concentrations considered were below the levels at which enzyme activity would be saturated with respect to oxygen. There was experimental difficulty with accurate $\mathrm{O}_{2}$ control for $\mathrm{O}_{2}$ levels below $0.4 \mathrm{mg} / \mathrm{L}$. Because the deviation from a linear response was not great (Fig. 5), for purposes of rate estimation $\mathrm{Mn}$ (II) oxidation rate was considered to be directly proportional to dissolved oxygen concentration across the entire range of $\mathrm{O}_{2}$ concentrations employed. The following relationship was used to account for the influence of $\mathrm{O}_{2}$ on the rate of $\mathrm{Mn}$ (II) oxidation:

$$
\left(\frac{k}{k_{r e f}}\right)_{O_{2}}=k_{O_{2}}\left[O_{2}\right]
$$

where $\left[\mathrm{O}_{2}\right]$ is the oxygen concentration in $\mathrm{mg} / \mathrm{L}$ and $\mathrm{k}_{\mathrm{O}_{2}}=$ $(8.05 \mathrm{mg} / \mathrm{L})^{-1}$ [note: $8.05 \mathrm{mg} / \mathrm{L}=\mathrm{O}_{2}$ saturation for air at $25^{\circ} \mathrm{C}$ and $0.05 \mathrm{~mol} / \mathrm{L}$ ionic strength (Tchobanoglous and Schroeder, 1985)].

\subsection{Effect of Temperature}

$\mathrm{Mn}(\mathrm{II})$ oxidation rates were determined at different temperatures, ranging from $10^{\circ} \mathrm{C}$ to $40^{\circ} \mathrm{C}$ at $\mathrm{pH}=7.5$, with added $\mathrm{Cu}=0$ and $100 \%$ air saturation at each temperature. Because dissolved oxygen was shown to affect the $\mathrm{Mn}$ (II) oxidation rate, the experimental results were all normalized to $\mathrm{O}_{2}=8.05$ $\mathrm{mg} / \mathrm{L}\left(100 \%\right.$ saturation at $\mathrm{T}=25^{\circ} \mathrm{C}$ and $\left.\mathrm{I}=0.05 \mathrm{~mol} / \mathrm{L}\right)$. The optimal temperature for $\mathrm{Mn}$ (II) oxidation was $\sim 30^{\circ} \mathrm{C}$ (Fig. 6). In comparison, an optimal temperature of $28^{\circ} \mathrm{C}$ for $L$. discophora SS1 was previously reported by Adams and Ghiorse (1987) in an undefined medium.

The increase in $\mathrm{Mn}(\mathrm{II})$ oxidation rate between 10 and $30^{\circ} \mathrm{C}$ is attributed to temperature activation of the reaction. The rate is expected to vary according to the Arrhenius equation in this region:

$$
\left(\frac{k}{k_{r e f}}\right)_{T}=A e^{-E_{a} / R T}
$$

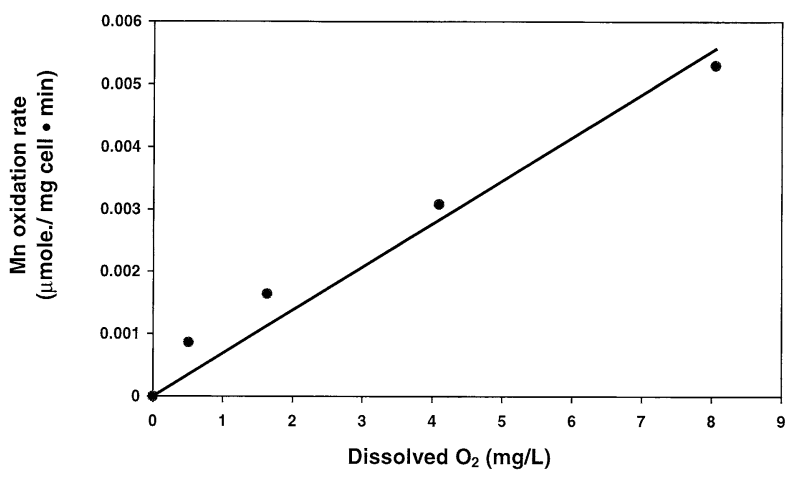

Fig. 5. Effect of dissolved oxygen concentration on Mn oxidation rate in the bioreactor at $\mathrm{T}=25^{\circ} \mathrm{C}, \mathrm{pH}=7.5$, and zero added $\mathrm{Cu}$. 


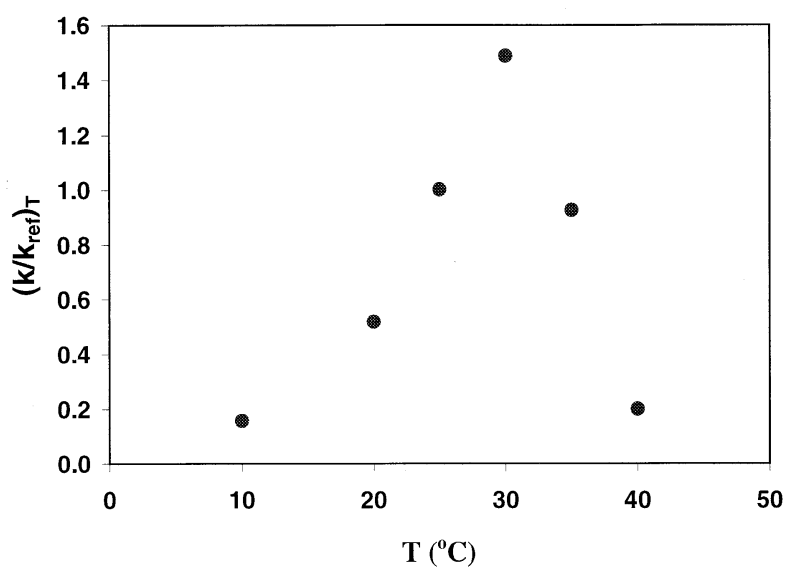

Fig. 6. Effect of temperature on Mn oxidation rate in the bioreactor at $\mathrm{pH}=7.5, \mathrm{O}_{2}=8.05 \mathrm{mg} / \mathrm{L}$, and zero added $\mathrm{Cu}$.

where $k=$ maximum reaction rate per cell unit, $E_{a}=$ activation energy, $A$ is a constant (equal to $e^{E_{d} / R T}$ when $\mathrm{T}=298 \mathrm{~K}$ ), and $T=$ absolute temperature.

A plot of $\ln k$ versus $1 / T$ (not shown) resulted in a line of slope $-E_{a} / R\left(r^{2}=0.99\right)$, giving an activation energy for $\mathrm{Mn}(\mathrm{II})$ oxidation reaction equal to $22.9 \mathrm{kcal} / \mathrm{g} \mathrm{mol}$.

The decrease in $\mathrm{Mn}$ (II) oxidation rate above $30^{\circ} \mathrm{C}$ was attributed to thermal deactivation of the Mn-oxidizing enzyme system. Although models have been proposed for thermal deactivation (e.g., Shuler and Kargi, 1992), insufficient data were obtained at high temperatures to permit a meaningful estimation of the model parameters.

\subsection{Effect of $\mathrm{Cu}$}

To test the effect of $\mathrm{Cu}$ on the growth and enzymatic $\mathrm{Mn}$ (II) oxidation activity of $L$. discophora $\mathrm{SS} 1, \mathrm{Cu}$ concentrations ranging from 0 to $0.15 \mu \mathrm{M}$ were added to the medium upon inoculation. Effects on cell growth rate and yield were determined in the shake flasks used for preparing a cell suspension for observation of $\mathrm{Mn}$ (II) oxidation kinetics, whereas effects on Mn oxidation were investigated in bioreactors containing cell suspensions grown in the presence of different $\mathrm{Cu}$ concentrations. At the level of zero added $\mathrm{Cu}$, which served as the reference condition for the experiments described above, a trace level of $\mathrm{Cu}$ may still be present in MMS medium as a reagent contaminant. $\mathrm{FeSO}_{4}$ was the sole reagent-grade chemical employed for which the manufacturer reported a metal impurity. Based on the manufacturer's specifications, the calculated concentration of $\mathrm{Cu}$ in $0.1 \mu \mathrm{mol} / \mathrm{L}$ reagent grade $\mathrm{FeSO}_{4}$ salt was less than $0.5 \mathrm{nM}$, and experimental measurement of copper concentration in MMS medium by specific ion electrode showed that the $\mathrm{Cu}^{+2}$ concentration was less than $1 \mathrm{nM}$. It was also possible that a $\mathrm{Cu}$ contaminant was introduced in the inoculum obtained from the initial culture of $L$. discophora in which peptone and yeast amendments were present. $\mathrm{A} \mathrm{Cu}$ concentration $=0.088 \mu \mathrm{mol} / \mathrm{L}$ was measured in the concentrated peptone plus yeast extract stock used for the initial culture. Dilution of this stock solution and the additional sequential dilution achieved through $\geq 2 \times$ transfer of inocula to MMS without added peptone and yeast extract give a maxi-

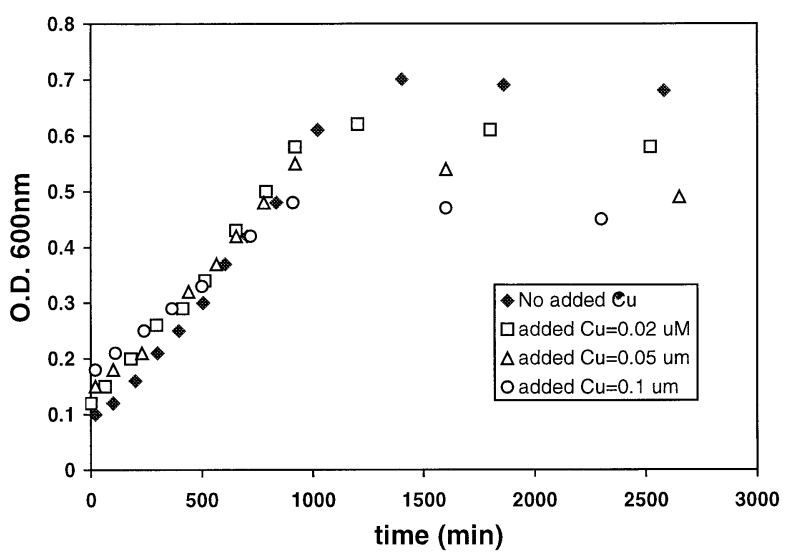

Fig. 7. Effect of added $\mathrm{Cu}$ on $L$. discophora $\mathrm{SS} 1$ growth curves in shake flask experiments at $\mathrm{pH}=7.5, \mathrm{~T}=25^{\circ} \mathrm{C}$, and $\mathrm{O}_{2}=8.05 \mathrm{mg} / \mathrm{L}$.

mum $\mathrm{Cu}$ concentration $=0.005 \mathrm{ng} / \mathrm{L}$ that could be carried over from a $\mathrm{Cu}$ impurity in the peptone and yeast extract solution. It is noteworthy that $L$. discophora produced an active $\mathrm{Mn}$ (II) oxidizing enzyme under the zero added $\mathrm{Cu}$ growth conditions, suggesting that either the cellular $\mathrm{Cu}$ requirement for synthesis of the putative copper-containing enzyme is extremely low $(\leq 0.5 \mathrm{nM})$, or that other metals may substitute for copper. In the latter regard, it is noteworthy that Nelson et al. (1999a) report inclusion of $0.1 \mu \mathrm{M}$ Fe was needed in the MMS growth medium (that contains no added $\mathrm{Cu}$ ) to obtain $L$. discophora cultures that actively oxidized $\mathrm{Mn}(\mathrm{II})$.

Experimental results for growth of $L$. discophora in the presence of $\mathrm{Cu}$ are shown in Figure 7 and the corresponding exponential growth rates are given in Table 3 . The exponential growth rate (Table 3 ) and the cell yield (Table 4) both decreased as added $\mathrm{Cu}$ increased. The lag phase of growth also increased as added $\mathrm{Cu}$ increased (data not shown). There was no growth observed within $5 \mathrm{~d}$ when $0.15 \mu \mathrm{mol} / \mathrm{L} \mathrm{Cu}$ was added upon inoculation.

The effect of $\mathrm{Cu}$ on cell yield can be modeled by the following empirical equation (@[Cu] less than $0.1 \mu \mathrm{M}$ ):

$$
Y=Y_{\max }\left(\frac{K_{I}}{K_{I}+[C u]}\right)
$$

where $Y$ is the cell yield, $Y_{\max }$ is the observed cell yield with zero added $\mathrm{Cu}, K_{I}$ is an inhibition constant, and $[\mathrm{Cu}]$ is the total copper concentration in $\mu \mathrm{mol} / \mathrm{L}$. A nonlinear least square data analysis gives $K_{I}=0.24 \mu \mathrm{mol} \mathrm{Cu} / \mathrm{L}\left(r^{2}=0.94\right)$.

Copper speciation may affect its bioavailability and toxicity.

Table 3. The effect of copper on the growth rate of L. discophora SS1 as determined in batch experiments in shake flasks.

\begin{tabular}{cc}
$\begin{array}{c}\text { Added } \mathrm{Cu} \text { concentration } \\
(\mu \mathrm{mol} / \mathrm{L})\end{array}$ & $\begin{array}{c}\text { Exponential growth rate } \\
\left(\mathrm{h}^{-1}\right)\end{array}$ \\
\hline 0 & 0.110 \\
0.02 & 0.102 \\
0.05 & 0.096 \\
0.1 & 0.072 \\
0.15 & 0 \\
\hline
\end{tabular}


Table 4. Effect of $\mathrm{Cu}$ on $L$. discophora SS-1 Mn oxidizing activity and cell yield (the yield and activity of a culture without added Cu(II) are defined as $100 \%)^{\mathrm{a}}{ }^{\mathrm{a}}$

\begin{tabular}{lccc}
\hline$[\mathrm{Cu}(\mathrm{II})] \mu \mathrm{M}$ & $\begin{array}{c}\text { Relative cell } \\
\text { yield, \% }\end{array}$ & $\begin{array}{c}\text { Mn(II) oxidizing } \\
\text { activity, \% }\end{array}$ & $\begin{array}{c}\text { Specific Mn(II) oxidizing activity } \\
\text { (per equal cell weight), \% }\end{array}$ \\
\hline 0 & 100 & 100 & 100 \\
0.02 & 94.7 & 118.4 & 125.0 \\
0.05 & 82.4 & 129.8 & 157.5 \\
0.1 & 70.2 & 132.6 & 189.0 \\
0.15 & 0 & N/A & N/A \\
\hline
\end{tabular}

$\mathrm{N} / \mathrm{A}=$ not applicable.

${ }^{a}$ Relative cell yields were determined in batch shake flask experiments, while Mn oxidizing activity was measured in bioreactors.

$\mathrm{Cu}$ speciation in MMS medium was calculated by MINEQL and is shown in Table 2. Because MMS medium contained no organic ligands with undefined metal binding properties (other than $1.5 \mathrm{nM}$ vitamin $\mathrm{B}_{12}$ ), the speciation of added $\mathrm{Cu}$ was entirely in the form of the free ion or as a complex with inorganic ligands. During the growth of $L$. discophora SS1, pH increased from the initial $\mathrm{pH}$ value of 6 to a final value of 7.8. Based on the calculations for $\mathrm{Cu}$ speciation (Table 2), the free $\mathrm{Cu}^{2+}$ concentration is expected to decrease from $84 \%$ of total $\mathrm{Cu}$ to $4 \%$ as the $\mathrm{pH}$ is increased from 6.0 to 7.5. This decrease is attributed almost entirely to the predicted formation of $\mathrm{Cu}(\mathrm{OH})_{2}$ (aq). Because the inorganic hydroxyl complexes of $\mathrm{Cu}$ are expected to be labile, the total $\mathrm{Cu}$ concentration in the defined MMS medium is expected to be approximately equal to the bioavailable $\mathrm{Cu}$ concentration. Therefore, the total $\mathrm{Cu}$ concentration was used in the model calculations.

In the MMS medium, added $\mathrm{Cu}$ as low as $0.02 \mu \mathrm{M}$ inhibited the growth rate and yield of $L$. discophora $\mathrm{SS} 1$, but $\mathrm{Cu}$ added at levels at and below $0.1 \mu \mathrm{M}$ stimulated the $\mathrm{Mn}$ (II) oxidation activity (Table 4). It is noteworthy that similar results were reported by Browers et al. (2000b) where an optimum $\mathrm{Cu}$ concentration of $40 \mu \mathrm{M}$ was reported for stimulation of $\mathrm{Mn}$ oxidation by $L$. discophora SS1. However this observation was obtained using a complex medium containing dissolved organic materials that could bind an undefined portion of the added $\mathrm{Cu}$, reducing the activity of the free cupric ion, and perhaps altering $\mathrm{Cu}$ bioavailability and reducing $\mathrm{Cu}$ toxicity to cells.

The stimulatory effect of $\mathrm{Cu}$ on $\mathrm{Mn}$ (II) oxidation can be modeled by the following empirical equation:

$$
\left(\frac{k}{k_{r e f}}\right)_{C u}=1+k_{C}[C u]
$$

where $k$ is the $\mathrm{Mn}$ (II) oxidation rate with added $\mathrm{Cu}$, and $k_{C}$ is a stimulation constant. A least square analysis for the data gives $k_{C}=8.8 /(\mu \mathrm{mol} / \mathrm{L})\left(r^{2}=0.97\right)$.

In a separate experiment, $\mathrm{Cu}$ was added to the supernatant of stationary cultures grown in standard MMS medium after removal of cells by centrifuging. Although $76 \%$ of the enzymatic activity for oxidation of $\mathrm{Mn}$ (II) remained in solution after separation of cells, no stimulatory effect of added $\mathrm{Cu}$ on $\mathrm{Mn}$ (II) oxidation was observed. This result suggests that actively growing cells are required for the $\mathrm{Cu}$ stimulation effect to occur, presumably through cellular incorporation of copper in the active site of the enzyme as postulated by Brouwers et al. (2000b).

\subsection{Rate Law for Biologic Mn(II) Oxidation}

Based on this research, the following equation may be used to describe biologic catalysis of $\mathrm{Mn}(\mathrm{II})$ as a function of $\mathrm{pH}$, cell concentration, $\mathrm{O}_{2}, \mathrm{Cu}$ concentration and temperature at $\mathrm{T} \leq$ $30^{\circ} \mathrm{C},\left[\mathrm{O}_{2}\right] \leq 8.05 \mathrm{mg} / \mathrm{L}$, and added $\mathrm{Cu} \leq 0.1 \mu \mathrm{M}$.

$$
\begin{aligned}
& \frac{d[M n(I I])}{d t}=\frac{k[X][M n(I I)]}{K_{S}+[M n(I I)]}\left(k_{o_{2}}\left[O_{2}\right]\right) \\
& \cdot\left(A e^{-E a / R T}\right)\left(\frac{k_{p H}}{1+\left[H^{+}\right] / K_{1}+K_{2} /\left[H^{+}\right.}\right)\left(1+k_{c}[C u(I I)]\right)
\end{aligned}
$$

where $[X]=$ cell concentration, $\mathrm{mg} / \mathrm{L} ;\left[\mathrm{O}_{2}\right]=$ dissolved oxygen concentration, $\mathrm{mg} / \mathrm{L} ;[\mathrm{Cu}]=$ total dissolved copper concentration, $\mu \mathrm{mol} / \mathrm{L} ; k=0.0059 \mu \mathrm{mol} \mathrm{Mn}(\mathrm{II}) /(\mathrm{mg}$ cell $\cdot \min )$; $K_{S}=5.7 \mu \mathrm{mol} \mathrm{Mn}(\mathrm{II}) / \mathrm{L} ; k_{\mathrm{o}_{2}}=1 / 8.05=0.124 \mathrm{~L} / \mathrm{mg}\left(\left[\mathrm{O}_{2}\right]=\right.$ $8.05 \mathrm{mg} / \mathrm{L}$ at $25^{\circ} \mathrm{C}$ and $\left.\mathrm{I}=0.05 \mathrm{~mol} / \mathrm{L}\right) ; E_{a}=22.9 \mathrm{kcal} /(\mathrm{g}$ cell $\cdot \mathrm{mol}) ; A=2.3 \times 10^{14} ; K_{1}=3.05 \times 10^{-8} ; K_{2}=2.46$ $\times 10^{-8} ; k_{p H}=2.82 ; k_{C}=8.8 \mathrm{~L} / \mu \mathrm{mol} \mathrm{Cu}$.

At $\mathrm{T}=25^{\circ} \mathrm{C}, \mathrm{pH}=7.5,\left[\mathrm{O}_{2}\right]=8.05 \mathrm{mg} / \mathrm{L}$ and zero added copper (i.e., $\mathrm{Cu}<5 \mathrm{nM}$ ), the above rate law for $\mathrm{Mn}$ (II) oxidation simplifies to the following equation:

$$
-\frac{d[M n(I I)]}{d t}=\frac{k[X][M n(I I)]}{K_{S}+[M n(I I)]}
$$

\subsection{Comparison of Biotic and Abiotic Mn Oxidation Rates}

The rate law for abiotic oxidation of $\mathrm{Mn}(\mathrm{II})$ is reported as (Morgan and Stumm, 1964; Morgan, 2001):

$$
-\frac{d[M n(I I)]}{d t}=k_{1}[M n(I I)]+k_{2}[M n(I I)]_{a q}[M n(I I I)]
$$

where $k_{1}$ is the rate constant for homogeneous oxidation and $k_{2}$ is the rate constant for catalysis by the oxide reaction product.

In the absence of an existing Mn oxide solid phase, the term for homogeneous oxidation governs the rate of the abiotic reaction. Because the abiotic $\mathrm{Mn}(\mathrm{II})$ oxidation reaction proceeds very slowly at circumneutral $\mathrm{pH}$, until recently values for $k_{1}$ had been reported only at $\mathrm{pH} 8.95$ and above (Davies and Morgan, 1989). Recently, Von Langen et al. (1997) reported $k_{1}$ values in seawater ranging from $1.1 \times 10^{-6}$ to $7.0 \times 10^{-6} / \mathrm{min}$ (normalized to $\mathrm{P}_{\mathrm{o}_{2}}=1 \mathrm{~atm}$ at $25^{\circ} \mathrm{C}$ ) over a $\mathrm{pH}$ range from 8.03 to 8.67. By way of comparison, the concentration of Mnoxidizing bacteria required to give a comparable biotic $\mathrm{Mn}(\mathrm{II})$ 
oxidation rate would be $0.30 \mu \mathrm{g} / \mathrm{L}$ at $\mathrm{pH} 8.03$ and $6.0 \mu \mathrm{g} / \mathrm{L}$ at $\mathrm{pH} 8.67$ (under similar normalized conditions of $\mathrm{P}_{\mathrm{o}_{2}}=1 \mathrm{~atm}$, at $25^{\circ} \mathrm{C}$, and assuming $[\mathrm{Mn}(\mathrm{II})] \ll K_{S}$ and $[\mathrm{Cu}]=0$ ). Thus, a relatively small population of bacteria capable of oxidizing $\mathrm{Mn}$ (II) is likely to be sufficient to ensure that the initial production of $\mathrm{Mn}$ oxide is dominated by biologic catalysis at circumneutral $\mathrm{pH}$ values.

This research, and the resulting rate equation (Eqn. 7) set the stage for incorporation of bacterially catalyzed $\mathrm{Mn}$ (II) oxidation kinetics into quantitative environmental models where $\mathrm{Mn}$ cycling is of direct interest. Additional applications would include modeling the effects of Mn(III/IV) oxide formation on the fate of toxic trace metals and other indirect effects of biologic Mn oxidation such as conversion of humic substances into metabolically available carbon substrates (Sunda and Kieber, 1994).

Acknowledgment-This research was supported, in part, by the following grants from the National Science Foundation: BES-9706715 and CHE-9708093. The authors thank three anonymous reviewers for their helpful suggestions with respect to modification of this paper.

Associate editor: J. P. Amend

\section{REFERENCES}

Adams L. F. and Ghiorse W. C. (1985) Influence of manganese on growth of a sheathless strain of Leptothrix discophora SS-1. Appl. Environ. Microbiol. 49, 556-562.

Adams L. F. and Ghiorse W. C. (1987) Characterization of extracellular Mn(II) oxidizing activity and isolation of and $\mathrm{Mn}$ (II) oxidizing protein from Leptothrix discophora SS1. J. Bacteriol. 169, 12791285.

American Public Health Association. (1995). Standard Methods for the Examination of Water and Wastewater, 19th ed. American Waterworks Association and the Water Environment Federation, Washington, DC.

Bailey E. J. and Ollis F. D. (1986) Biochemical Engineering Fundamentals. McGraw-Hill.

Boogerd F. C. and de Vrind J. P. M. (1987) Manganese oxidation by Leptothrix discophora. J. Bacteriol. 169, 489-494.

Brouwers G.-J., de Vrind J. P. M., Corstjens P. L. A. M., Cornelis P., Baysse C., de Vrind-de Jong E. W. (1999) CumA, a gene encoding a multicopper oxidase, is involved in $\mathrm{Mn}^{2+}$-oxidization in Pseudomonas putida GB-1. Appl. Environ. Microbiol. 65, 1762-1768.

Brouwers G.-J., Vijgenboom E., Corstjens P. L. A. M., de Vrind J. P. M., and de Vrind-de Jong E. W. (2000a). Bacterial Mn(II) oxidizing systems and multicopper oxidases: An overview of mechanisms and functions. Geomicrobiol. J. 17, 1-24.

Brouwers G.-J., Corstjens P. L. A. M., de Vrind J. P. M., Verkamman A., de Kuyper M., and de Vrind-de Jong E. W. (2000b) Stimulation of $\mathrm{Mn}(\mathrm{II})$ oxidation in Leptothrix discophora SS-1 by $\mathrm{Cu}(\mathrm{II})$ and sequence analysis of the region flanking the gene encoding putative multicopper oxidase MofA. Geomicrobiol. J. 17, 25-33.

Corstjens P. L. A. M., de Vrind J. P. M., Goosen T., and de Vrindde Jong E. W. (1997) Identification and molecular analysis of the Leptothrix discophora SS-1 mof A gene, a gene putatively encoding a manganese oxidizing protein with copper domains. Geomicrobiol. J. 14, 91-108.

Davies S. H. R. and Morgan J. J. (1989) Manganese(II) oxidationkinetics on metal-oxide surfaces. J. Colloid Interface Sci. 129, 6377.

Dickinson W. H., Caccavo F. Jr., Olesen B., and Lewandowski Z. (1997) Ennoblement of stainless steel by the manganese-depositing bacterium Leptothrix discophora. Appl. Environ. Microbiol. 60, 2502-2506.
Dong D. M., Nelson Y. W., Lion L. W., Shuler M. L., and Ghiorse W. C. (2000) Adsorption of $\mathrm{Pb}$ and $\mathrm{Cd}$ onto metal oxides and organic material in natural surface coatings as determined by selective extractions: New evidence for the importance of $\mathrm{Mn}$ and $\mathrm{Fe}$ oxides. Water Res. 34, 427-436.

Dzombak D. A. and Morel F. M. M. (1990) Surface Complexation Modeling. Hydrous Ferric Oxide. John Wiley, New York.

Ghiorse W. C. (1984) Biology of iron-depositing and manganesedepositing bacteria. In Annual Reviews of Microbiology (ed. L. N. Ornston). Ann. Reviews Inc., Palo Alto, CA. 38, 515-550.

Ghiorse W. C. and Chapnick S. D. (1983) Metal-depositing bacteria and the distribution of manganese and iron in swamp waters. Environ. Biogeochem. Ecol. Bull. (Stockholm) 35, 367-376.

Larsen E. I., Sly L. I., and McEwan A. G. (1999) Manganese(II) adsorption and oxidation by whole cells and a membrane fraction of Pedomicrobium sp. ACM 3067. Arch. Microbiol. 171, $257-$ 264.

Luoma S. N. and Bryan G. W. (1981) A statistical assessment of the form of trace metals in oxidized estuarine sediments employing chemical extractants. Science of the Total Environment 17, 165196.

Moffett J. W. (1997) The importance of microbial Mn oxidation in the upper ocean: A comparison of the Sargasso Sea and equatorial Pacific. Deep Sea Research, Part I-Oceanographic Research Papers 44, 1277-1291.

Morgan J. J. (2001). Heterogeneous vs. homogeneous redox reaction rates of manganese in water. Preprint extended abstract. 221st National Meeting of the American Chemical Society, San Diego, CA, April 1-5. 41, 914-918.

Morgan J. J. and Stumm W. (1964) Colloid-chemical properties of manganese dioxide. J. Colloid Sci. 19, 347.

Nealson K. H., Tebo B. M., and Rosson R. A. (1988) Occurrence and mechanisms of microbial oxidation of manganese. Adv. Appl. Microbiol. 33, 279-318.

Nelson Y. W., Lion L. W., Ghiorse W. C., and Shuler M. L. (1999a) Production of biogenic Mn oxides by Leptothrix discophora SS-1 in a chemically defined growth medium and evaluation of their $\mathrm{Pb}$ adsorption characteristics. Appl. Environ. Microbiol. 65, 175180.

Nelson Y. M., Lion L. W., Shuler M. L., and Ghiorse W. C. (1999b) Lead binding to metal oxide and organic phases of natural aquatic biofilms. Limnol. Oceanogr. 44, 1715-1729.

Shuler M. L. and Kargi F. (1992) Bioprocess Engineering. Basic Concepts. Prentice-Hall, Englewood Cliffs, NJ.

Staley J. T. (1968) Prosthecomicrobium and Ancalomicrobium: New prosthecate freshwater bacteria. J. Bacteriol. 95, 1921-1942.

Stumm W. and Morgan J. J. (1996) Aquatic Chemistry. John Wiley and Sons, New York.

Sunda W. D. and Kieber D. J. (1994) Oxidation of humic substances by manganese oxides yields low molecular-weight organic substrates. Nature 367, 62-64.

Tchobanoglous G. and Schroeder E. D. (1985) Water Quality. Addison-Wesley, CA.

Tebo B. M. and Emerson S. (1986) Microbial manganese (II) oxidation in the marine environment: A quantitative study. Biogeochemistry 2, $149-161$.

Tebo B. M., Ghiorse W. C., van Waasbergen L. G., Siering P. L., and Caspi R. (1997) Bacterially mediated mineral formation: Insights into manganese (II) oxidation from molecular genetic and biochemical studies. In Reviews in Mineralogy, 36. Geomicrobiology: Interactions Between Microbes and Minerals (eds. J. F. Banfield and K. H. Nealson), pp. 225-266. Mineralogical Society of America, Washington, DC.

Tessier A., Fortin D., Belzile N., Devitre R. R., and Leppard G. G. (1996) Metal sorption to diagenetic iron and manganese oxyhydroxides and associated organic matter: Narrowing the gap between field and laboratory measurements. Geochim. Cosmochim. Acta 60, 387 404.

van Waasbergen L. G., Hildebrand M., and Tebo B. M. (1996) Identification and characterization of a gene cluster involved in manga- 
nese oxidation by spores of the marine Bacillus sp. strain SG- 1. J. Bacteriol. 178, 3517-3530.

Von Langen P. J., Johnson K. S., Coale K. H., and Elrod V. A. (1997) Oxidation kinetics of manganese(II) in seawater at nanomolar concentrations. Geochim. Cosmochim. Acta 61, 4945-4954.

Vuceta J. and Morgan J. J. (1978) Chemical modeling of trace metals in fresh water: Role of complexation and adsorption. Environ. Sci. Technol. 12, 1302-1308.

Westall J. C., Zachary J. L., and Morel F. M. M. (1976) MINEQL, a computer program for the calculation of chemical equilibrium composition of aqueous system. Technical note 18. Department of Civil Engineering, Massachusetts Institute of Technology, Cambridge. 